\title{
Tobin's $Q$ as an Indicator of Firm Performance: Empirical Evidence from Manufacturing Sector Firms of Pakistan
}

Submitted 13/12/20, $1^{\text {st }}$ revision 16/01/21, $2^{\text {nd }}$ revision 22/02/21, accepted 20/03/21

\author{
Maryam Ishaq ${ }^{1}$, Yasir Islam ${ }^{2}$ and Ghulam Ghouse ${ }^{3}$
}

\begin{abstract}
:
Purpose: The study econometrically investigates the misperceived connection between improved firm performance (measured through scale efficiency and cost discipline) and Tobin's $Q$ for 51 manufacturing sector firms of Pakistan.

Design/Methodology/Approach: Using firm-level data, panel least squares regression estimator is employed to test if the firms' improved operating efficiency (measured through (i) scale efficiency, and (ii) cost discipline) bears statistically significant impact on Tobin's $Q$. To gauge the sustainability and robustness of acquired results, cross-section regression estimator is also applied.

Findings: With high statistical significance, we tend to reject our hypothesized relationship between firm performance and Tobin's $Q$. Subject to the relative importance of scale decisions versus cost disciplines of firms, their declining performance (in terms of underinvestments) is found to be either bearing no impact or inflating Tobin's $Q$.

Practical Importance: Inflating values of Tobin's $Q$ raise importance of poor scale decisions. Therefore, scale efficiency, reflected in firm's managerial decisions, holds substantial importance in determining Tobin's $Q$. The analysis also confirms ignorable role of cost discipline in describing Tobin's $Q$, thus negating the much-advocated contribution of cost disciplines in determining firm performance.

Originality/Value: To the best of authors' knowledge, no study has been done so far on Pakistani firms, empirically investigating how effectively firms' performance can be reflected through Tobin's $Q$. The paper makes novel contribution to the existing research works on the subject as (i) advance econometric procedures are applied, and (ii) robustness of results are not only verified across two different econometric estimators but also against alternative measures of Tobin's $Q$, scale efficiency and cost discipline, highlighting their relative importance.
\end{abstract}

Keywords: Firms' financial performance, scale efficiency, cost discipline, varianceconsistent panel regression estimator, cross-section regression estimator.

JEL codes: $C 22, C 23, C 24, G 300, G 310$.

Paper Type: Research study.

${ }^{1}$ Dr. Corresponding author, Assistant Professor of Economics at Department of Economics,

The University of Lahore, Lahore, Pakistan.E-mail: maryam.ishaq@econ.uol.edu.pk;

${ }^{2}$ Student of LLB at State University of New York, New York, U.S.A.

${ }^{3}$ Dr. Assistant Professor of Economics at Department of Economics, The University of

Lahore, Lahore, Pakistan. 


\section{Introduction}

Tobin $\mathrm{Q}$ is the economic theory of investment behavior which measures the performance of a business firm. ' $Q$ ' is the ratio of the market value of the existing shares (share capital) to the replacement cost of the total physical assets. Tobin's Q is widely used proxy for gauging the operating performance of businesses in studies of corporate governance (Brainard and Tobin, 1968). Alternatively, firm's operational efficiency is believed to be taken analogous to its ability to make optimal resource utilization. This will lead firm to produce quality goods and services at suitable cost, so that higher profit margins could be maintained on sustainable basis. The operational performance from an investment market perspective means that an investor must pay the lowest fee to earn high profit. Therefore, operational performance can be taken as the ability of management to maximize the shareholders wealth by improving the market value of the share price through successful business operations.

The phenomenon of corporate governance holds vital importance in the discussions of operating efficiency of firms. In general, cooperate governance refers to the ability of the top management to follow ethical legal and moral obligations through leadership approach to create value for all the stakeholders. Corporate governance refers to the structures and processes by which companies are directed and controlled (Fernando, 2012). Good corporate governance helps companies operate more efficiently, improves access to capital, mitigate risk and safeguard against mismanagement to build stakeholders confidence. It makes companies more accountable and transparent to investors thus, serving as tool to respond to stakeholders' concerns. Firms with more shareholders rights are better governed as shareholders influence managers to create value for them which in turn impacts Tobin's Q (Gompers and Metrick, 2003).

But it is observed that shareholders influence managers to invest in risky projects which often holds strong implications for achieving financial and non-financial goals of a business. When managers finance a project through more equity, they have pressure from shareholders to create high return which often results in the overinvestment, thus enduring more risks for the project. When managers use debt, they are more responsible due to debt covenants (agreement between mangers and bank to sue them if they use debt in an irresponsible manner) and are less influenced by shareholders and create value for the business and stakeholders in a more independent environment (Schmidt, 2006).

Dybvig and Warachka (2015) state that there is an endogeneity problem when Tobin's Q is used to measure the economic implications for corporate governance. The endogeneity is the change in variable which arises from within a model or system. It has been seen that when projects are financed through debts, Tobin's Q is endogenous with respect to the managerial decisions regarding a firm's operational scale with underinvestment inflating Tobin's Q. The theoretical framework produced by Dybvig and Warachka (2015) is derived from the managerial decisions 
related to the production decisions and the cost discipline of firms. The quantity produced by many firms are too small relative to their potential capacity of production. This is because when managers take debt, they are more conscious or responsible and invest in safe projects in order to manage risks (Myers, 1977).

Managers in this way produce less relative to firm's productive capacities, therefore, ending up in underinvestment (Smith and Barclay, 1995). The managerial entrenchment in this discussion is of key importance as in their urge of using debt more responsibly, managers try to demonstrate a more responsible behavior and are more controlled by debt financing. To managers, bankruptcy is the loss of reputation, benefits, control, and incentives of the firm (Grossman and Hart, 1982). So, managers use debt financing in normal circumstances with suitable micro- and macro-economic analysis to increase the value of the firm through underinvestment but, producing less than the full capacity to achieve the positive net present value.

Managers create value for the firm and stakeholders this way instead of choosing a track where they could have invested in more profitable projects (Yermack, 2004; Bates et al., 2008). This points to managers' reluctance in decision making, holding strong implications for maximization of shareholders' wealth. Such a behaviour on part of managers obstructs the plausible inter-relationship between Tobin's Q and the firm performance. For achieving operational efficiency, it is the prime responsibility of the managers to maximize firm's net value of invested capital which is analogous to maximizing firm's net present value. Nevertheless, the element of uncertainty associated with dynamic and challenging business environment, Tobin's Q remains unable to address this concern. As per Tobin's Q theory, an ideal manager is one, maximizing the firm's market value of its invested capital, thus leading to improvement in market share price and the value of firm's total physical assets. But it has been seen that managers use underinvestment strategy as they operate at (relatively) smaller scale, helping to control the cost.

Consequently, this prevents from fulfilling the prime objective of value maximization of the firm. Thus, maximizing Tobin's $Q$ does not maximize the firm's value, as underinvestment increases Tobin's $Q$ from the perspective of maximizing shareholder wealth, it is optimal to increase investment until a firm's marginal profit is zero. This suggests confusing implications of firm's better performance for Tobin's Q. Where better operating efficiency in terms of scale (production) is accused of bringing a fall to Tobin's Q (by mitigating underinvestment), better operating efficiency in terms of cost discipline on other hand is acclaimed of inflating Tobin's Q. The relative importance of scale decisions versus cost discipline implies that the net impact of better operating efficiency on Tobin's Q is ambiguous as high return on assets can either be attributed to underinvestment or stringent cost discipline. The economic implications of corporate governance, arising from the managers' behaviour, bears implications for the operating efficiency which further creates implications for the value maximization of firm's stock and physical assets (Bertrand and Mullainathan, 2003). 
The present research is an empirical exploration of firm-level data from 51 Pakistani (manufacturing sector) firms, investigating if the Tobin's Q is a good indicator of firm performance. The study will make a good contribution in the existing works on this subject as no commendable paper has so far researched this area using sophisticated econometric procedures. Applying econometric estimators on sample data set will not only unveil the significance of (perceived) interrelationship between Tobin's Q and firm performance but will also help readers to understand the relative importance of scale efficiency and cost discipline in determining the trend behaviour of Tobin's Q. Also, for the purpose of establishing reliability and consistency of results, the study employs alternative measures of Tobin's Q and firm performance, generating distinctive and (theoretically) different suggestion for future empirical research in this area.

\section{Literature Review}

Tobin's Q is widely used proxy for the operating performance in studies of corporate governance. The operating efficiency or performance is defined as the measurement of the management's ability to generate sales revenue and to control cost (Heyman and Vlachos, 2009). The managers create value for the firm through strategic planning and control (Graham and Harvey, 2001). Graham et al. (2002) state that firms have lower normalize valuations than acquiring firms as managers are more focused on their incentives which they receive debt improving EPS (earning per share) and valuation of stock through underinvestment. This behavior of the managers is due to the managerial entrenchment indicating weak corporate governance, thus improving Tobin's Q for a short while (Core et al., 1999). The valuation of the stock, replacement cost of physical assets and overall net present value of the firm starts declining after some time. Higher cost and operating inefficiency become evident therefore, contradicting the desirable values of Tobin's Q. The decrease in the value of the stock also becomes inevitable in such circumstances, hence shaking the confidence of the shareholders (Hua and Wang, 1995). This diminishes the value of Tobin's $Q$, and likewise in case of scale and cost disciplines, the implication is that when increasing output to a level where marginal profit gets zero also reduces the Tobin's Q which again questions the eligibility of Tobin's $\mathrm{Q}$ as a measure of firm performance.

Jensen and Meckling (1976) state that the self-interested behavior of the shareholder bears strong implications for how much debt a company takes, as shareholders influence managers to invest in risky projects. In the event of failure, consequences are with debt holders, so there is a conflict of interest among shareholders, managers, and debt holders. This phenomenon is known by the name of 'The Agency Cost Theory Problem'. The agency cost theory problem bears two-fold effects for the value of Tobin's Q. When a project is financed through debt, there would be underinvestment which pushes up Tobin's $Q$ in the short run. And in longrun, Tobin's $Q$ behaves in reverse manner as operating efficiency declines due to the cost and scale decisions. When managers use more equity for financing a project, they are forced (by shareholders) to invest in risky projects, thus 
transferring value away from bondholders to shareholders (Myers, 1977). It is evident that the low-risk assets reduce the replacement cost which triggers the share price to fall and thus makes Tobin's Q to behave oddly.

Whilst evaluating Tobin's Q as a measure of firm performance, two new measures of operating efficiency are widely used. The first measure normalizes firm's gross profit to measure its scale efficiency (Hoyle and Doupnik, 2012). The other one normalizes firm's operating expenses to measure its cost discipline. The scalerelated measure is based on the accounting data, which is endogenous, being extracted from managerial decisions. The presence of endogeneity is likely to affect normalization of the gross profits and operating expenses, resultantly affecting the measurement of firm's operating efficiency (Dybvig and Warachka, 2015). For developing a better understanding, gross profit is the total revenue minus cost of sales divided by total sales revenue. The depreciation and amortization are part of operating expenses, but amortization is an intangible cost difficult to determine.

Hence the measure of the gross profits and the operating expenses as a measure of operating efficiency does not sufficiently support the phenomenon of Tobin's Q. Alternatively, measuring operating performance through capital and sales, normalizing gross profits by capital ensures that scale efficiency is isolated and normalizing operating expenses by capital isolates cost discipline. Now, technically, a higher ratio of gross profits to capital indicates deteriorating operating efficiency, the firm being operating below its efficient scale ${ }^{4}$, thus making Tobin's $Q$ as an inefficient measure of firm's performance (Giroud and Mueller, 2010). The inability of Tobin's Q to serve as a good indicator of firm performance is also reflected through the measurement of capital proxied through book value of total assets (property, plant and equipment, PPE).

However, total assets also undertake some intangible assets like goodwill, brand loyalty, etc. which are difficult to estimate, thus, once again rendering Tobin's $Q$ an inappropriate measure of operating efficiency. Another approach is to substitute capital with sales in the denominator. Nevertheless, normalization by sales cannot measure cost discipline unambiguously (Anderson and Reeb, 2003). This shows that operating efficiency measure becomes rather inefficient in the instance of normalization with sales, thus hampering the explanatory power of Tobin's Q (Fridson, and Alvarez, 2011; Hoyle and Doupnik, 2012). John and Litov (2010) state that high credit ratings are associated with managers' conservatism, thus, the impact of underinvestment on Tobin's $Q$ is strongest in firms who have unhindered access to debt financing.

The firms with more access to debt financing have better ratings as companies with strong profitability raising the debt can contribute to the improvement of the company's performance. The debt financing, for those companies with poor profitability can deteriorate their gearing and performance (Xiao-Yan and Tao,

\footnotetext{
${ }^{4}$ Capital is inclusive of the intangible assets such as patents and brand equity.
} 
2008). The firms with more access to debt financing prefer to invest in those projects which are comparatively safe. Mangers therefore prefer underinvestment to enhance the value of the Tobin's Q but this scheme behaves differently in short-run and in the long-run in such an instance. As for the long run, the declining value of the stock as well as that of the replacement cost of the total physical assets render Tobin's Q an inefficient measure of firm's performance. When managers take secured debt, they are bound to invest in safe projects and therefore, often remain unable to address key business projects to take competitive advantage. This is because of the element of risk which raises under-investment problem. The firms in financial distress will avoid investments in profitable business projects as the benefits will go to bond holder first, being priority of the payment rules.

Hence, when the managers foresee that the impact of debt on gearing is high, they try to avoid debt financing, otherwise, they may meet a situation where company may end up into bankruptcy. Stulz, and Johnson (1985) suggest certain ways to alleviate the under-investment problem. Issuing debt with high priority (secured debt-an indirect restriction on investment policy) can alleviate the under-investment problem and may increase the value of the firm for two reasons (a) secured debt reduces debt holders monitoring costs since, the collateral cannot be sold to pay the dividend or can be exchanged for a riskier asset. Also, secured creditors are less likely to require restrictive covenants, and (b) secured debt makes it more advantageous to undertake a positive NPV projects. This underinvestment problem first inflates the value of Tobin's $Q$ in short-run, followed by a subsequent fall in long-run, thus making the measure a less precise representative of firm performance.

Song and Liu (2008) state that the distinction between cash flow rights and the control rights leads to the asset substitution problem and the agency costs of debt financing. The cash flow rights and the control rights when separated implies that the free cash flow rights and the control of the asset rights are with the different parties (like managers and shareholders), thus, preventing the company from investing (independently) in the potential business projects. When the cash flow rights and control rights are with the shareholders or managers, they then follow their own plans and ignore the strategic plans of the company. The long-term competitiveness of the company therefore gets affected with the cash flow and control rights are separated as the agency cost and the managerial entrenchment leads to the decrease in the value of Tobin's Q (Jensen and Meckling, 1976; Cronqvist, 2009).

Gompers and Metrick, (2003) state that here is an inverse relation between the managerial entrenchment index (G-Index) and Tobin's Q, followed by the fact that less managerial entrenchment improves firm performance. Operating efficiency when substituted in place of Tobin's Q, suggests that low value of G-Index (implying less managerial entrenchment) is linked with low firm performance. As higher Tobin's Q can be a consequence of underinvestment problem (instead of the better firm performance), underinvest and poorly managed cost discipline in firms 
is due to the weak corporate governance, bearing strong economic implications for achieving strategic objectives of the organization (Bebchuk et al., 2009; Erikson and Whited, 2006; Erikson and Whited, 2012).

The management accounting metrics include net profit margin and return on equity, net profit, dividend, shareholders equity, and net assets to judge the performance of the company (Drury, 2012). One may therefore think of considering Return on Equity (ROE) and Return on Assets (ROA) as proxies of efficiency measures in the discussions on Tobin's Q as representative of firm performance. The ROE is the net income divided by the shareholders equity (net income/shareholders equity). It measures the firm's profitability yielded through shareholders money. The market value of the equity divided by the replacement cost can be taken equivalent to Tobin's Q. More the value of the shareholders equity, replacement cost in this instance would inflate Tobin's Q. Higher value of total physical assets (replacement cost) implies market value of the equity will be less than one thus yielding an undervalued Tobin's Q.

Similarly, if the value net income is high (relative to shareholders' equity) this would increase ROE substantially (Kaplan and Atkinson, 2015). In either case, there are costs involved in form of intangible assets like advertising and research and development, goodwill and depreciation and amortization which are difficult to determine. Cremers and Nair (2005) regard Tobin's Q a less effective performance measure as profit, costs and the value of shareholders equity all behave differently in the short-run and in the long-run. Aghion and Bolton (1992) state that the financing structure influences the result of the mergers and acquisitions (M\&A) by affecting the distribution of the voting rights and the price of M\&A. The financial structure with more equity provides shareholder a chance to influence the decisions around M\&A, as they put much influence on the firm decisions (Giroud and Mueller, 2011).

Simerly and Li (1999) are of the view that in financial management practices, it is of vital importance to craft a capital structure which maximizes shareholder wealth and profitability of the business. But when firm takes debt in the capital structure, shareholders may exercise little influence on the firm and excessive managerial entrenchment makes it difficult to achieve the competitive advantage (Custodio, 2014).

Overall, there is a mix of evidence on the legitimacy of Tobin's Q as an efficient and reliable measure of firm performance. Earlier research also suggest that the precision of Tobin's Q is further complicated using different proxies and the constituent elements of Tobin's Q, since different measures behave differently in short-run as well as in long-run. Therefore, efficiency of Tobin's Q cannot be concluded with certainty, unless a concrete empirical verification of the estimator is done using reliable firm-level data sets. 


\section{Theoretical Framework}

For empirical validation of Tobin's Q efficiency for measuring firm performance, the study adapts the theoretical settings from the work of Dybvig and Warachka (2015) done along the similar line of research. The forthcoming discussions under this section will comprise of establishing suitable proxies in favor of firm's operating efficiency measures. This will ultimately lead to the empirical verification of hypothesized relationship between improved corporate governance and firm performance in the best possible way, given the availability of data set and applicability of various econometric testing procedures.

The firm performance in this study is taken analogous to its operating efficiency. There are quite a few proxies available for measuring firm operating efficiency, however, following the footsteps of Dybvig and Warachka (2015), we choose firm's (a) scale decisions, and (b) its cost discipline to account for its operating efficiency. Scale decisions refer to the number of units of output firm opts to produce. By the virtue of firms' per unit (of output) market price and cost of its output sold, it is legitimate to think of linking output with firm's gross profit. Dybvig and Warachka (2015) study rests on some strong theoretical assumptions around market behavior of the firm, referring it to be imperfect (monopolistic), particularly in terms of scale decisions. For example, marginal revenue of the firm is decreasing (owing to its downward sloping demand curve), its slope determines the size of its potential market, therefore, firm's degree of monopoly in product market. Also, marginal cost of output is increasing since the firm is faced with decreasing returns to scale. These two assumptions combine to establish a convincing fact about the decreasing (diminishing) marginal profits of the firm.

The empirical investigation of proposed relationship between corporate governance and firm performance involves a set of three proxy variables. Talking about the model regress and first, the firm performance is taken analogous to Tobin's Q which is a ratio of firm's market value to its capital. The numerator of Tobin's q proxy comprises of sum of book value of total assets (BVTA) and market value of its equity (MVE) minus the book value of equity (BVE). The firm capital in the denominator is represented through the book value of total assets (BVTA).

$Q_{1}=q_{1 t}=\frac{B V T A+M V E-B V E}{B V T A}$

However, for the purpose of simplicity, Chung and Pruitt (1994) suggest an easier approximation of Tobin's Q which is substantially conservative in terms of data requirements and computational efforts involved.

$$
Q_{2}=q_{2 t}=\frac{\left(M V E_{i t}+M V D_{i t}\right)}{B V T A_{i t}}
$$


where MVE stands for market value of equity, a product of firm's share price and the number of common stock shares outstanding. MVD represents market value of firm's short-term liabilities net of its short-term assets. The final (useable) form of this new measure of Tobin's Q involves creating a ratio of sum of MVE and MVD to book value of total assets (BVTA). The new alternative proxy of Tobin's Q differs from previous one primarily since it implicitly takes the replacement cost of firm's plants, equipment, and inventories analogous to their book value.

On part of model regressors i.e., measures of firm's operating efficiency (and hence firm performance), two proxies are used, each for firm's scale efficiency $\left(R_{1 y t}\right.$ and $\left.R_{2 y t}\right)$ and its cost discipline $\left(R_{1 c t}\right.$ and $\left.R_{2 c t}\right)$. The first measure of scale efficiency $\left(R_{1 y t}\right)$ is the ratio of firm's gross profit to the book value of its total assets. Here, gross profit is the yield of net sales minus cost of goods sold. Replacing the denominator of first measure (i.e., book value of total assets) with firm's net sales yields the second measure of scale efficiency $\left(R_{2 y t}\right)$.

$$
R_{1 y t}=\frac{\text { Gross Profit }}{\text { Book Value of Total Asset }} \quad, \quad R_{2 y t}=\frac{\text { Gross Profit }}{\text { Sales }}
$$

Talking about the other dimension of firm performance i.e., its cost discipline, its basic measure $\left(R_{1 c t}\right)$ is represented through the ratio of firm's operating expenses to the book value of its total assets. Here, operating expense of firm is mainly the summation of its distributive and administrative expense. Once again, interchanging the denominator of first measure (i.e., book value of total assets) with firm's net sales yields the second measure of $\left(R_{2 c t}\right)$.

$R_{1 c t}=\frac{\text { operating Expense }}{\text { Book Value of Total Asset }} \quad, R_{2 c t}=\frac{\text { Operating Expense }}{\text { Sales }}$

We now are in a position to produce a mathematical demonstration of the (plausible) inter-relationship between Tobin's Q $\left(q_{t}\right)$ and the two measures of firm performance (i.e scale efficiency $\left(R_{y t}\right)$ and cost discipline $\left(R_{c t}\right)$ ) through below stated equation.

$q_{t}=\vartheta_{y} R_{y t}+\vartheta_{c} R_{c t}$

\section{Empirical Methodology and Results}

For empirically estimating the established model (equation 5'), two distinct econometric approaches are used. The first one comprises of panel least squares regression estimator. As mentioned earlier, our panel is homogenous, containing a cross-section of 51 manufacturing sector firms of Pakistan for a period of five year i.e., 2012 to 2016 . Therefore, the proposed model requires to control for industry fixed and year fixed effects. 
$q_{i t}=\vartheta_{y} R_{y, i t}+\vartheta_{c} R_{c, i t}+\delta X_{i}+\varepsilon_{i t}$

Equation (5") is the estimable version of our proposed model. Here, $X_{i t}$ is a vector of industry-fixed and year-fixed effects. It is natural to assume that errors from equation (5") can possibly be clustered i.e., observations in group $i$ can be correlated in some unknown way, as well as correlations in corresponding errors ${ }^{5}$ $\left(\varepsilon_{i t}\right)$. As a consequence, to clustered errors, regression coefficients from equation (5') would be still unbiased, but the associated standard errors may be seriously wrong, thus giving rise to misleading inferences.

To combat the above stated issue, we manage to obtain variance-consistent regression errors, where the standard errors of the regression coefficients will be clustered at industry-level ${ }^{6}$. The panel regression is run with fixed effects ${ }^{7}$, where error components are modelled under the belief that every observation within the group is equally and well-correlated with every other observations of the group. However, the assumption of zero correlation across groups is maintained.

Panel data estimations hold some caveats in the form of various econometric intricacies. As mentioned by Dybvig and Warachka (2015), errors-in variables defined as $R_{y}-E\left[R_{y}\right]$ and $R_{c}-E\left[R_{c}\right]$ may cause substantial deviations in our estimates from those predicted under our theoretical model established above. Also, the time-varying trends in $E\left[R_{y}\right]$ and $E\left[R_{c}\right]$ may emerge, thus serving as a serious violation of the assumption martingale cash flows. Another serious concern raised in their paper discusses the possibility of deviations of operating efficiency (the Tobin's q) from their optimal levels, as caused by friction in investment. The divergence of observed values of operating efficiency from their optimal levels may thus translate into erroneous regression results.

To mitigate such issues, we verify the robustness of our pooled data results using cross-section regression estimator. Using five-year period averages of $q, R_{y}$ and $R_{c}$, we seek to obtain more consistent and robust regression estimates, since, the problem of errors-in-variables can be effectively fixed once the single-period cash flows are replaced by their medium-term or long-term counterparts.

Recalling the theoretical predications made in the preceding section of the paper, the null hypothesis of our both types of regression estimators assumes that Tobin's $\mathrm{Q}$ being an efficient measure of firm's performance (i.e., scale efficiency and cost discipline), cross-firms disparities in Tobin's Q are purely driven by cost discipline

\footnotetext{
${ }^{5}$ For example, this may happen because of common or correlated response of industries towards a policy shock or some sudden economic event at regional and/or national level.

${ }^{6}$ The panel regression model with variance-consistent errors is estimated through STATA using its routine vce (cluster industry).

${ }^{7}$ The panel regression model with fixed effects is estimated through STATA using its routine xtreg,fe.
} 
(only). Therefore, to validate the efficiency of Tobin's $Q$ as a valid measure of firm performance, theta coefficients on cost discipline and scale efficiency must be negative and zero (besides holding desirable statistical significance), respectively i.e., $\vartheta_{c}<0$ and $\vartheta_{y}=0$. However, a positive $\vartheta_{y}$ suggests rising values of Tobin's $\mathrm{Q}$, induced by under-investments. This behavior is in sharp contrast with the empirical evidence from prior studies on this line of research, associating large values of Tobin's Q with improved firm performance (i.e., improving volumes of investment).

As elaborated under theoretical framework developed above, the measure of Tobin's Q is structured under two distinct compositions: one with firm's equity as the sole mean of its financing and the other one allowing both equity and debt as mode of firm's financing. The robustness of our results is not only checked across two different measures of Tobin's Q but also through varying measures of scale efficiency and cost discipline, where their denominators (being book value of total assets) are interchanged with firm's total sales. We run three individual sets of panel regressions, where (i) scale efficiency is the only regression parameter and its denominator (the book value of total assets) is equally substitutable with firm's sales, and (ii) cost discipline is the only regression parameter and its denominator (the book value of total assets) is equally substitutable with firm's sales, and finally (iii) Tobin's Q is hypothesized to be explained by both scale efficiency and cost discipline, firstly as a ratio of total assets and then as a ratio of firm's sales.

\subsection{Sample Data and Model Variables}

The theoretical relationship established between firm performance and its determinants (equation 5') are empirically tested through yearly observations gathered from public accounts of 51 manufacturing sectors firms of Pakistan, listed on Pakistan Stock Exchange, published in their annual reports. The data period for subject firms ranges from year 2012 to 2016 and are from sectors such as sugar, textile, food, chemical, petroleum, paper and engineering goods.

Referring to our model variables, the composition of first measure of Tobin's Q (equation 1) involves book value of total assets, book value of equity and market value of equity. The book value of total asset is fixed assets fewer intangible assets. The book value of total equity comprises of total asset fewer total liabilities. The market value of equity is calculated through the number of outstanding shares multiplied by market price. The market price for each share price is taken on yearly average basis from Khistock website. The composition of second measure of Tobin's Q and model regressors is straightforward and is described in the above section.

\subsection{Results and Discussion}


Table 1 reports the panel regression results, using first measure of Tobin's Q as model regressed. Against all three sets of regression estimators, our theoretical predications about scale efficiency are successfully met. With no single exception, the coefficient values on $\vartheta_{y}$ have always turned out to be statistically insignificant (up to 90 percent confidence interval), indicating no role of scale efficiency in Tobin's Q. However, the coefficient values on $\vartheta_{c}$ are intuitively incorrect since half of the coefficient values are zero and rest of the half are statistically insignificant (at 5 percent statistical significance). This suggests ignorable role of cost discipline in describing Tobin's Q, thus (partly) rejecting the null hypothesis of our regression model which was proposing significant contributions of cost discipline in driving firm's performance.

Table 2 reports the panel regression results against second measure of Tobin's Q. Our model turns out to behave even more oddly when second measure of Tobin's Q is taken into consideration. Unlike the previous case, the theta coefficients on $R_{y}$ from three sets of regression estimations yield mixed evidence on the validity of proposed behavior of Tobin's Q against scale efficiency. $\vartheta_{y}$ coefficients from regressions with firms' sales in denominator of $R_{y}$ are statistically insignificant, thus establishing the fact that scale efficiency has no power to drive Tobin's Q. On contrary, the coefficients obtained from regressions with firms' total assets in denominator of $R_{y}$ are positive and statistically significant, thus suggesting significant effects of firm's under-investment on Tobin's Q. These findings are in line with those of Dybvig and Warachka (2015). On part of cost discipline, we strongly tend to reject the null hypothesis, as every time $\vartheta_{c}$ coefficient either turns out to be positive and statistically significant or it becomes zero, thus declining the plausible role of cost discipline in explaining Tobin's Q.

Table 1. Panel Regression Estimates for Evaluating Tobin's $Q$ as an Indicator of Firm Performance

\begin{tabular}{|c|c|c|}
\hline \multicolumn{3}{|c|}{$\operatorname{Tobin}^{\prime} s Q_{1}=q_{1 i t}=\frac{\left(B V T A_{i t}+M V E_{i t}-B V E_{i t}\right)}{B V T A_{i t}}$} \\
\hline & $\vartheta_{y}$ & $\vartheta_{c}$ \\
\hline$R_{y_{-} T A}$ & $\begin{array}{l}0.29 \\
{[0.66]}\end{array}$ & - \\
\hline$R_{y_{-} \text {Sales }}$ & $\begin{array}{l}0.03 \\
{[1.17]}\end{array}$ & - \\
\hline$R_{c_{-} T A}$ & - & $\begin{array}{l}0.68 \\
{[0.42]}\end{array}$ \\
\hline$R_{c_{-} \text {Sales }}$ & - & $\begin{array}{c}-0.00 * * * \\
{[-5.03]}\end{array}$ \\
\hline$R_{y_{-} T A}+R_{c_{-} T A}$ & $\begin{array}{l}0.37 \\
{[0.68]}\end{array}$ & $\begin{array}{l}-0.68 \\
{[-0.44]}\end{array}$ \\
\hline $\boldsymbol{R}_{y_{-} \text {Sales }}+\boldsymbol{R}_{c_{-} \text {Sales }}$ & $\begin{array}{l}0.06 \\
{[1.60]}\end{array}$ & $\begin{array}{l}-0.00 * * * \\
{[-4.03]}\end{array}$ \\
\hline
\end{tabular}


NOTES

(i) *,** and *** are showing significance of coefficients at 10\%, 5\% and $1 \%$ significance level, respectively.

(ii) t-values are given in squared-brackets.

Source: Own study.

Table 2. Panel Regression Estimates for Evaluating Tobin's $Q$ as an Indicator of Firm Performance

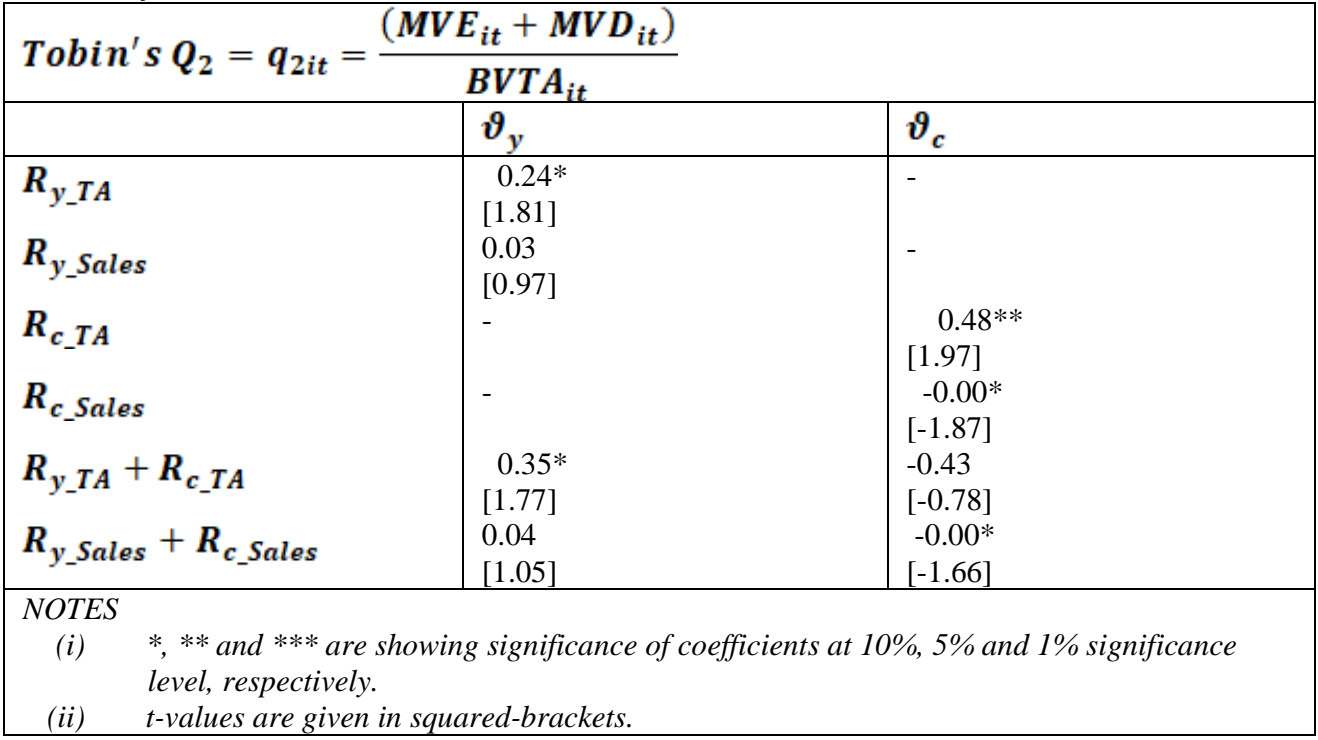

Source: Own study.

Tables 3 and 4 demonstrate the results from cross section regressions. First, discussing the regression estimates against first measure of Tobin's Q (Table 3), the results are rather encouraging, both in terms of scale efficiency and cost discipline. Large number of theta coefficients on $R_{y}$ favor the acceptance of null hypothesis, suggesting (statistically) no significant role of scale efficiency in explaining the movements of Tobin's Q. Overall, the cross-sectional regression estimates under first measure of Q largely advocate Tobin's Q as a valid measure of firm's performance i.e., both scale efficiency and cost disciplines.

In contrast to our cross-sectional regression estimates obtained against first measure of Q, the results acquired for second measure tend to reject our null hypothesis with high statistical significance. Looking into TABLE 4, all the theta coefficients on $R_{y}$ are positive and statistically significant (at better than 1 percent significance level). This finding is consistent with underinvestment's ability to inflate Tobin's q, and contradicts the prior literature's assumption that a higher Tobin's $q$ is an evidence of better firm performance. On the other hand, cost discipline is establishing somewhat ambiguous relationship with Tobin's Q because, $\vartheta_{c}$ coefficients are turning out to insignificant as well as significant (with positive and negative values). 
Table 3. Cross-Section Regression Estimates for Evaluating Tobin's $Q$ as an Indicator of Firm Performance

\begin{tabular}{|c|c|c|}
\hline $\operatorname{Tobin}^{\prime} s Q_{1}=q_{1 i}$ & $\frac{A_{i}+M V I}{B V T A}$ & \\
\hline & $\beta_{r y}$ & $\beta_{r c}$ \\
\hline$r_{y_{-} T A}$ & $\begin{array}{l}-0.70 * * \\
{[-1.93]}\end{array}$ & - \\
\hline$r_{y \_ \text {Sales }}$ & $\begin{array}{l}0.27 \\
{[0.57]}\end{array}$ & - \\
\hline$r_{c_{-} T A}$ & - & $\begin{array}{l}-1.97 * * * \\
{[-3.17]}\end{array}$ \\
\hline$r_{c_{-} \text {Sales }}$ & - & $\begin{array}{l}-0.00 \\
{[-0.43]}\end{array}$ \\
\hline$r_{y_{-} T A}+r_{c_{-} T A}$ & 0.97 & $-3.49 * * *$ \\
\hline$r_{y_{-} \text {Sales }}+r_{c_{-} \text {Sales }}$ & $\begin{array}{l}{[1.42]} \\
0.32 \\
{[038]}\end{array}$ & $\begin{array}{l}{[-2.03]} \\
0.00 \\
{[0.06]}\end{array}$ \\
\hline NOTES & & \\
\hline $\begin{array}{ll}\text { (i) } & *, * * \text { and } * \\
& \text { level, respe } \\
\text { (ii) } & \text { t-values are }\end{array}$ & significan & $\%, 5 \%$ and $1 \%$ significance \\
\hline
\end{tabular}

Source: Own study.

Table 4. Cross-Section Regression Estimates for Evaluating Tobin's $Q$ as an Indicator of Firm Performance

\begin{tabular}{|c|c|c|}
\hline \multicolumn{2}{|c|}{ 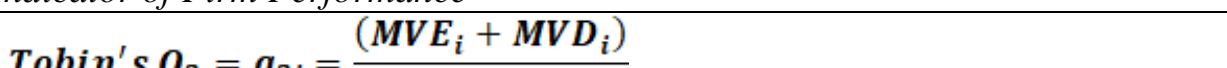 } & \\
\hline & $\beta_{\text {ry }}$ & $\beta_{r c}$ \\
\hline$r_{y_{-} T A}$ & $\begin{array}{l}0.39 * * * \\
{[2.39]}\end{array}$ & - \\
\hline$r_{y \_ \text {Sales }}$ & $0.37 * * *$ & - \\
\hline & {$[2.78]$} & 024 \\
\hline$r_{c_{-} T A}$ & - & $\begin{array}{l}0.24 \\
{[0.77]}\end{array}$ \\
\hline$r_{c_{-} \text {Sales }}$ & - & $\begin{array}{l}-0.00 \\
{[-1.02]}\end{array}$ \\
\hline$r_{y T A}+r_{c T A}$ & $1.11 * * *$ & $\begin{array}{r}-1.50 * * * \\
-1.02]\end{array}$ \\
\hline$y_{-} I A-c_{-} I A$ & [3.59] & {$[-2.68]$} \\
\hline$r_{y_{-} \text {Sales }}+r_{c_{-} \text {Sales }}$ & $\begin{array}{l}1.02 * * * \\
{[3.95]}\end{array}$ & $\begin{array}{l}0.01 * * * \\
{[2.87]}\end{array}$ \\
\hline \multicolumn{3}{|l|}{ NOTES } \\
\hline (i) & ng significance & $\%, 5 \%$ and $1 \%$ significance \\
\hline
\end{tabular}

Source: Own study.

\section{Conclusion}


The study carefully estimates the professed impact of firm performance on Tobin's Q. Under a simple theoretical framework, it empirically investigates the misperceived connection between improved firm performance and Tobin's Q for 51 manufacturing sector firms of Pakistan but finds it indefinite. Subject to the relative importance of scale decisions versus cost discipline of firms, their declining performance (in terms of under-investments) is found to be either bearing no impact or inflating Tobin's Q with high statistical significance. The later type of findings brings into limelight the importance of poor scale decisions in explaining the higher values of Tobin's Q. These findings commensurate with those of Dybvig and Warachka (2015), however, less evidently found in other studies on the similar line of research. Hence, declining our proposed research hypothesis, scale efficiency, reflected in firm's managerial decisions, holds substantial importance in determining Tobin's Q. The analysis also confirms ignorable role of cost discipline in describing Tobin's Q, thus negating the much-advocated contribution of cost disciplines in determining firm performance.

The paper stands out from earlier research on the subject, owing to the robustness statistical estimates it offers. The hypothesized relationship between Tobin's Q and firm performance is investigated under (a) two well-distinct econometric estimators, accounting for different data dimensions (panel regression and cross-section regressions extracted from time-series averages of data), and (b) two well-defined proxies of Tobin's Q, proposing different means of firms financing (through equity only and equity plus debt) as well as (intuitively) varying measures of scale efficiency and cost discipline.

Interestingly, across two types of estimation approaches as well as against two different compositions of Tobin's Q, the results are substantially contrasting, suggesting (somewhat) ambiguous impact of firm performance on Tobin's Q. This calls for a careful selection of statistical estimators as well as proxy measures of model variables whilst conducting future research on the area, the obtained results being evidently sensitive to the said aspects of empirical investigation of our proposed model.

\section{References:}

Aghion, P., Bolton, P. 1992. An Incomplete Contracts Approach to Financial Contracting. The Review of Economic Studies, 59(3), 473-494.

Anderson, R.C., Reeb, D.M. 2003. Founding-Family Ownership and Firm Performance: Evidence from the S\&P 500. The Journal of Finance, 58(3), 1301-1328.

Barclay, M.J., Smith Jr, C.W. 1995. The Maturity Structure of Corporate Debt. The Journal of Finance, 50(2), 609-631.

Bates, T.W., Becher, D.A., Lemmon, M.L. 2008. Board Classification and Managerial Entrenchment: Evidence from the Market for Corporate Control. Journal of Financial Economics, 87(3), 656-677.

Bebchuk, L., Cohen, A., Ferrell, A. 2009. What Matters in Corporate Governance? The Review of Financial Studies, 22(2), 783-827. 
Bertrand, M., Mullainathan, S. 2003. Enjoying the Quiet Life? Corporate governance and Managerial Preferences. Journal of Political Economy, 111(5), 1043-1075.

Brainard, W.C., Tobin, J. 1968. Pitfalls in Financial Model Building. The American Economic Review, 58(2), 99-122.

Chung, K.H., Pruitt, S.W. 1994. A Simple Approximation of Tobin's q. Financial Management, 70-74.

Core, J.E., Holthausen, R.W., Larcker, D.F. 1999. Corporate Governance, Chief Executive Officer Compensation, and Firm Performance. Journal of Financial Economics, 51(3), 371-406.

Cremers, K.M., Nair, V.B. 2005. Governance Mechanisms and Equity Prices. The Journal of Finance, 60(6), 2859-2894.

Cronqvist, H., Heyman, F., Nilsson, M., Svaleryd, H., Vlachos, J. 2009. Do Entrenched Managers Pay their Workers More? The Journal of Finance, 64(1), 309-339.

Custodio, C. 2014. Mergers and Acquisitions Accounting and the Diversification Discount. The Journal of Finance, 69(1), 219-240.

Drury, C.M. 2013. Management and Cost Accounting. Springer.

Dybvig, P.H., Warachka, M. 2015. Tobin's Q Does Not Measure Firm Performance: Theory, Empirics, and Alternatives. Empirics, and Alternatives, March.

Erickson, T., Whited, T.M. 2012. Treating Measurement Error in g's q. Review of Financial Studies 25(1), 1286-1329.

Erickson, T., Whited, T.M. 2006. On the Accuracy of Different Measures of Q. Financial Management, 35(3), 5-33.

Fridson, M.S., Alvarez, F. 2011. Financial Statement Analysis: A Practitioner's Guide, Vol. 597. John Wiley \& Sons.

Fernando, A.C. 2011. Corporate Governance: Principles, Polices and Practices, 2/E. Pearson Education India.

Giroud, X., Mueller, H.M. 2010. Does Corporate Governance Matter in Competitive Industries? Journal of Financial Economics, 95(3), 312-331.

Giroud, X., Mueller, H.M. 2011. Corporate Governance, Product Market Competition, and Equity Prices. The Journal of Finance, 66(2), 563-600.

Gompers, P., Ishii, J., Metrick, A. 2003. Corporate Governance and Equity Prices. The Quarterly Journal of Economics, 118(1), 107-156.

Graham, J.R., Lemmon, M.L., Wolf, J.G. 2002. Does Corporate Diversification Destroy Value? The Journal of Finance, 57(2), 695-720.

Graham, J.R., Harvey, C.R. 2001. The Theory and Practice of Corporate Finance: Evidence from the Field. Journal of Financial Economics, 60(2-3), 187-243.

Hoyle, J.B., Schaefer, T.F., Doupnik, T.S. 2011. Advanced Accounting, 350-357. New York, NY: McGraw-Hill Irwin.

He, H., Wang, J. 1995. Differential Information and Dynamic Behavior of Stock Trading Volume. The Review of Financial Studies, 8(4), 919-972.

Jensen, M., Meckling W. 1976. Theory of the Firm: Managerial Behaviour, Agency Costs and Capital Structure. Journal of Financial Economics 44(3), 305-360.

John, K., Litov, L. 2010. Managerial Entrenchment and Capital Structure: New Evidence. Journal of Empirical Legal Studies, 7(4), 693-742.

Kaplan, R.S., Atkinson, A.A. 2015. Advanced Management Accounting. PHI Learning.

Myers, S.C. 1977. Determinants of Corporate Borrowing. Journal of Financial Economics, 5(2), 147-175.

Simerly, R.L., Li, M. 2000. Environmental Dynamism, Capital Structure and Performance: A Theoretical Integration and an Empirical Test. Strategic Management Journal, 21(1), 31-49. 
Schmidt, K.M. 2006. The Economics of Covenants as a Means of Efficient Creditor Protection. European Business Organization Law Review, 7(1), 89-94.

Stulz, R., Johnson, H. 1985. An Analysis of Secured Debt. Journal of Financial Economics, 14(4), 501-521.

Xing, L.I.U., Song X.B. 2007. Effects of Controlling Shareholders Agency on Debt Financing Agency Costs: Analysis based on Real Options. Systems EngineeringTheory and Practice, 27(9), 61-68.

Xiao-Yan, L., Tao, L. 2008. Risk Management and Engineering Management, 2008, ICRMEM 08, International: Research on Effect of Debt Financing in Electric Power Listed Companies, Journal of Finance, 43, 532-567.

Yermack, D. 2004. Remuneration, Retention, and Reputation Incentives for Outside Directors. The Journal of Finance, 59(5), 2281-2308. 